\title{
DEVELOPMENT TEXTBOOKS E-COMMERCE FOR GROWING ENTREPRENEURSHIP SKILLS
}

\author{
Rito Cipta Sigitta H. ${ }^{1)}$, Rizki Noor Prasetyono ${ }^{2)}$ \\ Fakultas Sains dan Teknologi Universitas Pradaban \\ Jl. Raya Pagojengan Km.3 Paguyangan Kab. Brebes 52276 Telp. 0289-432032 \\ Email : ${ }^{1}$ rintocipta13@gmail.com
}

\begin{abstract}
In the digital and disrupt era 4.0 requires innovation in meeting human needs, especially in commerce. The purpose of this study is to increase student interest in entrepreneurship through e-commerce textbooks. This research is a research and development research with ADDIE model. Product validity data collection using questionnaires and tests to find out the increase in entrepreneurship. The results of data analysis and discussion can be concluded that from the development of e-commerce teaching materials validation of material experts, media experts and peers shows that products in the excellent category are appropriate to use. Small group product trials obtained an ideal percentage of $85.2 \%$ and were categorized very well. The results of the analysis of increasing entrepreneurial skills from the use of e-commerce teaching materials obtained an N-Gain value of 0.45 , indicating that e-commerce development to improve entrepreneurship capacity is effective and appropriate for use in the learning process.
\end{abstract}

Keywords: textbooks, e-commerce, entrepreneurial skills.

\section{Pendahuluan}

Di era digital dan disruptif 4.0 membutuhkan inovasi dalam memenuhi kebutuhan manusia, khususnya dalam perdagangan. Tahun 2000an internet belum berkembang seperti sekarang ini, penjualan produk atau proses perdagangan masih menggunakan cara konvensional. Proses penjualan dilakukan secara langsung dengan penjual, pembeli dan proses jual beli terjadi. Proses perkembangan terjadi sekarang banyak model perbelanjaan berbasis online. Munculnya teknologi dan informasi yang berkembang pesat memotong proses jual beli menjadi lebih ringkas. Jual beli ini dilakukan tidak langsung bertemu antara penjual dan pembeli, akan tetapi dengan pihak ketiga berupa platform yang menyediakan jasa untuk menyambungkan antara penjual dan pembeli. Pihak ketiga yang sekarang banyak digunakan dimasyarakat indonesia ini seperti Tokopedia, Bukalapak, Beli-Beli, dan lain sebagainya.

Indonesia menerima dampak perkembangan teknologi informasi dan komputer ini salah satunya aplikasi penjualan online yang merambah dunia perdagangan. Bahkan menurut Febriantoro [1] indonesia yang mengikuti Asean Economic Community (AEC) tahun 2016 para pegiat dunia usaha memiliki pemikiran inovatif untuk pengemembangan dunia bisnisnya, salah satunya dengan menggunakan ICT (Information, Communication, Tecnology). Mata \& Hernández [2] juga menyatakan dalam penelitianya bahwa konsep $e$ commerce mampu menambah dan mengembangkan produk dan pemasaranya secara masif. Bahkan teknologi sangat penting dalam penyampaian informasi dengan memaksimalkan manajemen dan teknisi akan menciptakan system informasi yang handal [3]. Dapak ini juga merambah kedalam berbagai bidang seperti dunia pendidikan dan kehidupan sosial. 
Pendidikan paling cepat terkena dampak akibat perkembangan teknologi dan informasi, dalam hal ini Sekolah menengah Kejuruan (SMK). Sekarang SMK memiliki jurusan yang mengenai teknologi dan informasi. Bahkan konsentrasi dalam penjurusan di SMK lebih spesifik ke pengembangan perangkat lunak yaitu rekayasa perangkat lunak. Arifianto \& Coiri [4] menyebutkan bahwa penerepan yang manyakut teknologi informasi dalam hal ini e-commerce mampu meningkatkan pemahaman siswa dalam pembelajaran manajemen usaha kecil dan menengah. Seprina, dkk [5] dalam penelitiannya mengenai motivasi siswa SMK berwirausaha, menujukan hal yang positif melalui penggunaan $e$ commerce. Laudon \& Traver [6] dalam e-commerce untuk siswa sangat bagus untuk pembelajaran dunia bisnis khususnya untuk siswa yang akan lulus dan sudah lulus sekolah. Dari beberapa penelitian tersebut, $e$-commerce sangat dibutuhkan dalam perkembangan siswa SMK untuk menambah minat dalam berwirausaha.

Dari paparan permasalahan diatas maka dapat dirumuskan permasalahan yaitu bagaimana mengembangkan bahan ajar e-commerce untuk menumbuhkan minat siswa dalam berwirausaha. Jadi tujuan penelitian ini yaitu untuk meningkatkan minat siswa dalam berwirausaha melalui bahan ajar e-commerce.

\section{Metodologi Penelitian}

\section{Jenis Penelitian}

Penelitian ini merupakan penelitian research and development dengan model ADDIE yang dikembangakan oleh Dick and Carry sesuai dengan gambar 3.2 berikut :

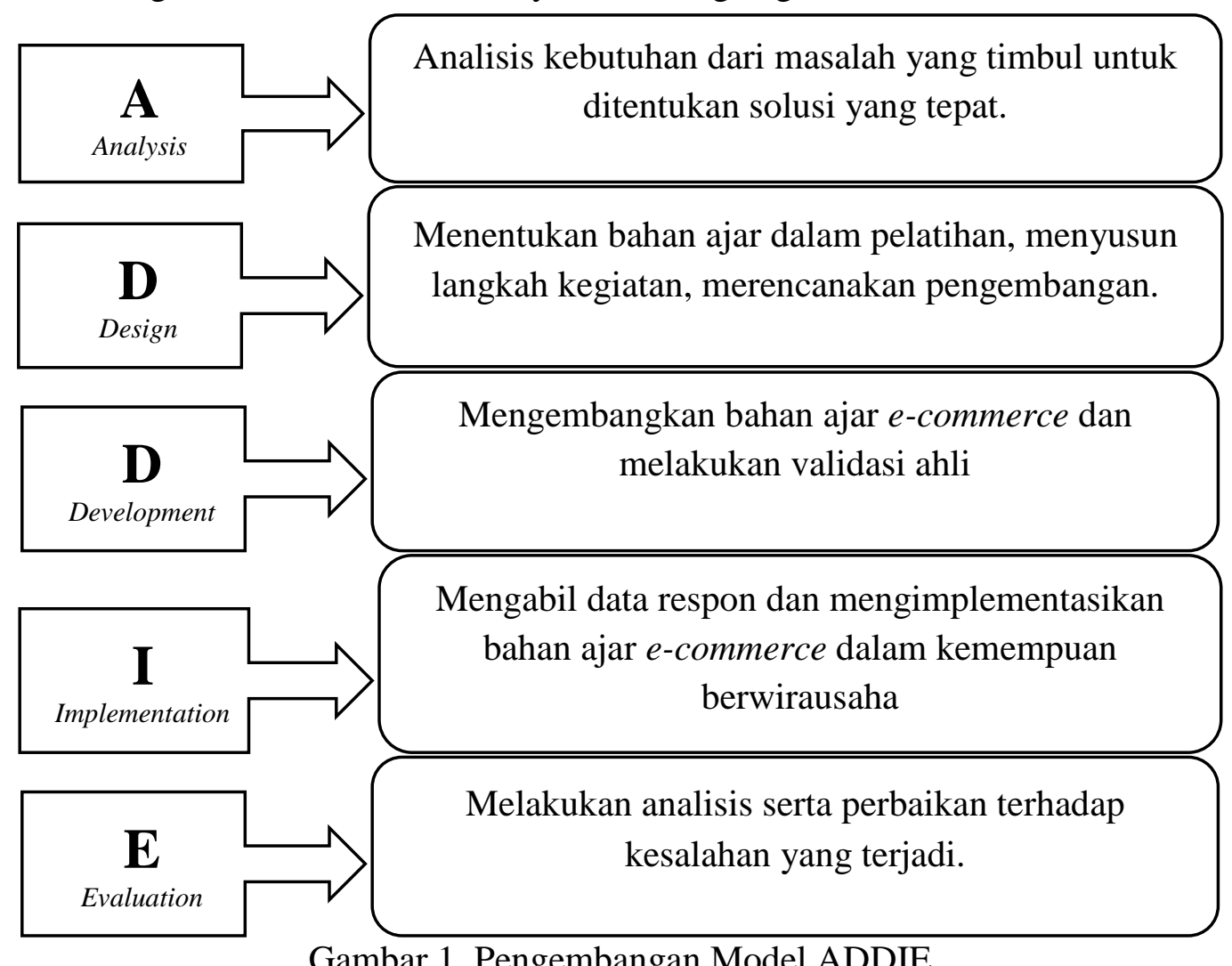

Gambar 1. Pengembangan Model ADDIE

Tahapan pengembangan bahan ajar e-commerce berbasis web dijelaskan sebagai berikut :

1) Analysis (analisis)

Tahapan ini dilakukan analisis dari beberapa aspek dalam kebutuhanya untuk pengembangan bahan ajar ini. Aspek yang diamati dari tahapan ini adalah dari segi 
kurikulum sekolah, wawancara dari guru pengajar, kemudian dari aspek siswa dan buku yang mereka gunakan selama pembelajaran.

2) Design (Desain)

Hasil analisis kebutuhan menunjukan bahwa perlunya pengembangan bahan ajar. Pada tahap ini dilakukan perencanaan dalam mengembangkan bahan ajar e-commerce berbasis web. Membuat instrumen validasi dan angket respon untuk bahan ajar e-commerce berbasis web. Kemudian menentukan validator yang akan menilai bahan ajar e-commerce berbasis web.

3) Development (Pengembangan)

Setelah dilakukan perencanaan desain kemudian dilakukan tahap pengembangan bahan ajar e-commerce berbasis web. Dengan menambahkan aspaek keterampilan berwirausaha melalui konten yang berisi e-commerce. Kemudian melakukan validasi produk oleh guru mata pelajaran, ahli media, dan ahli materi. Dari hasil validasi oleh validator kemudian akan dianalisis apakah bahan ajar e-commerce berbasis web ini layak digunakan atau direvisi untuk diimplementasikan dalam kegiatan.

4) Implementation (Implementasi)

Tahapan ini bahan yang sudah divalidasi akan dilakukan uji coba pada sampel kecil atau secara terbatas kemudian diambil data angket respons. Setelah itu dilakukan pelaksanaan penggunaan bahan ajar e-commerce berbasis web dalam skala besar. Kemudian diambil data angket respons pada kelas yang menerapkan bahan ajar e-commerce berbasis web.

5) Evaluation (Evaluasi)

Pada tahap ini melakukan revisi dan perbaikan akhir yang diambil berdasakan angket respons atau masukan siswa. Hal ini ditujukan untuk bahan ajar e-commerce berbasis web bisa digunakan oleh sekolah yang lebih luas lagi.

\section{Sampel Penelitian}

Data penelitian diambil di SMK Karya Bhakti Brebes dengan sampel penelitian jumlah total 30 Mahasiswa. Pengambilan data menggunakan cluster random sampling yaitu dari 4 kelas dipilih satu kelas yaitu kelas XI RPL 1.

\section{Metode Pengumpulan Data}

Metode Anget yaitu pengumpulan data validitas produk menggunakan angket atau kuesioner, berisi pernyataan-pernyataan yang ditujukan kepada ahli materi, ahli media, teman sejawat dan pengguna. Metode Tes yang diguanakan yaitu untuk mengukur peningkatan siswa berwirausaha. Instrument tes terdiri dari soal kemampuan awal dan kemampuan akhir.

\section{Analisis Data Penelitian}

Analisis data produk untuk mengetahui validitas dari produk setelah diuji pakar dan uji coba sekala kecil sesuai dengan table 1 .

Tabel 1. Skor untuk Penilian Produk

\begin{tabular}{|l|l|c|}
\hline Kategori & Skor & Rentang Skor Kuantitatif \\
\hline Sangat Baik (SB) & 4 & $\bar{X}>(M+1.5 \mathrm{Si})$ \\
\hline Baik (B) & 3 & $M<\bar{X} \leq(M+1.5 \mathrm{Si})$ \\
\hline Kurang (K) & 2 & $(M-1.5 \mathrm{Si})<\bar{X} \leq M$ \\
\hline Sangat Kurang (SK) & 1 & $\bar{X} \leq(M-1.5 \mathrm{Si})$ \\
\hline
\end{tabular}

Analisis untuk menguji peningkatan kemempuan berwirausaha dari penggunaan bahan ajar e-commerce dengan :

$$
\text { gain }=\frac{\text { skor post tes }- \text { skor pretes }}{\text { Skor maksimum }- \text { skor pretes }}
$$

Kriteria gain sebagai berikut :

Tinggi $: g \geq 0,7$ 
Sedang : $0,7>\mathrm{g} \geq 0,3$

Rendah : $\mathrm{g}<0,3$.

\section{Hasil dan Pembahasan}

Kontribusi penelitian pengembangan bahan ajar e-commerce yaitu memberikan wawasan bahwa perlunya buku, materi, maupun panduan untuk mengetahui pembuatan $e$ commerce yang sedang berkembang di era digital saat ini. Perbedaan dengan penelitian ini dengan yang lain yaitu sebagian besar penelitian mengenai e-commerce hanya terpusat dalam pengembangan system informasinya, web design, analisis platform, dan sebagainya. Seperti pada penelitian Farlina dkk [7] menujukan hasil penelitian mengenai pengembangan dari web e-commerce yang berintegrasi dengan SMS gateway, dimana penelitian ini berfokus pada pengembangan web e-commerce saja. Li \& Guan [8] menunjukan penelitian mengenai analisis mengenai pendalaman pengembangan e-commerce didaerah pedesaan, penenelitian hanya berfokus pada mengembangan desa komersil. Heshmati dkk [9] juga memganalisis mengenai proses yang terjadi pada e-commerce yaitu pada sektor pengiriman dan dampak dari penggunaanya. Bandara dkk [10] juga hanya fokus meneliti mengenai prakiraan mengenai permintaan dalam e-commerce dengan menggunakan metode neural network. Dari keempat penelitian tersebut bisa disimpulkan masing-masing mempunyai fokus subtansi isi dari e-commerce. Sedikit yang mengembankan diluarr subtansi e-commerce yaitu pengembangan buku, bahan ajar, materi maupun panduan membuat e-commerce secara keseluruhan dari awal sampai akhir pembuatanya.

Pengembangan buku ajar memberikan pemahaman ketika dikemas dengan baik sehingga memberikan kontribusi dalam memperoleh pengetahuan mengenai ilmu yang akan dipelajari [11]. Di SMK Karya Bhaakti untuk mempengaruhi dalam pengetahuan pembelajaran mengenai e-commerce diperlukan pengembangan buku e-commerce, seperti pada penelitian Daulay [12] menunjukan bahwa bahan ajar yang terdistributif dengan baik melalui teknologi infomasi memberikan kemudahan akses siswa dalam mendapatkan ilmu. Tegeh dan Kirna [13] berpendapat bahwa dalam pengembangan bahan ajar melalui penyusunan yang matang diataranya pengumpulan materi, gambar/grafik yang digunakan untuk menjelaskan, dan tata letak dan pengetikan yang menarik bagi pembaca. Dari pengembangan bahan ajar ini di dapatkan validasi ahli materi, ahli media, dua guru mata pelajaran, dan teman sejawat.

Hasil perhitungan validasi ahli materi didapatkan presentase keidealan produk didapatkankan $76,7 \%$ termasuk dalam rentang skor $\bar{X}>62,5 \%$ dalam kategori. Untuk peritungan presentase keidealan tiap aspek sesuai dengan tabel 2 .

Tabel 2. Presentase dari Ahli Materi

\begin{tabular}{|c|c|c|}
\hline Aspek & Persentase dari skor keidealan (\%) & Kategori \\
\hline 1. Aspek isi & 75 & Sangat baik \\
\hline 2. Akurasi materi & 75 & Sangat baik \\
\hline 3. Merangsang Keingintahuan & 83,3 & Sangat baik \\
\hline 4. Penyajian & 87,5 & Sangat baik \\
\hline $\begin{array}{l}\text { 5. Penggunaan Web dengan } \\
\text { php dan dreamweaver }\end{array}$ & 70 & Baik \\
\hline
\end{tabular}

Kemudian dari hasil perhitungan presentase keidealan produk sesuai dengan validasi ahli media didapatkankan $70 \%$ termasuk dalam rentang skor $\bar{X}>62,5$ dalam kategori Baik. Untuk peritungan presentase keidealan tiap aspek sesuai dengan tabel 3. 
Tabel 3. Presentase dari Ahli Media

\begin{tabular}{|l|c|l|}
\hline \multicolumn{1}{|c|}{ Aspek } & Persentase dari skor keidealan (\%) & \multicolumn{1}{|c|}{ Kategori } \\
\hline 1. Penyajian & 80 & Sangat baik \\
\hline 2. Tampilan umum & 100 & Baik \\
\hline 3. Bahasa/ Keterbacaan & 100 & Baik \\
\hline $\begin{array}{l}\text { 4. Penggunaan Web dengan } \\
\text { php dan dreamweaver }\end{array}$ & 75 & Sangat baik \\
\hline
\end{tabular}

Perhitungan presentase keidealan produk sesuai dengan validasi Guru Kelas didapatkankan $84,78 \%$ termasuk dalam rentang skor $\bar{X}>81,25 \%$ dalam kategori sangat baik. Untuk peritungan presentase keidealan tiap aspek sesuai dengan tabel 4.

Tabel 4. Presentase dari Guru Kelas

\begin{tabular}{|ll|c|c|}
\hline \multicolumn{1}{|c|}{ Aspek } & Persentase dari skor keidealan (\%) & Kategori \\
\hline 1. & Aspek isi & 93,75 & Sangat baik \\
\hline 2. Akurasi materi & 81,25 & Sangat baik \\
\hline 3. Merangsang Keingintahuan & 87,5 & Sangat baik \\
\hline 4. Penyajian & 80 & Sangat baik \\
\hline 5. Tampilan Umum & 85 & Baik \\
\hline 6. Bahasa \& Keterbacaan & 87,5 & Sangat baik \\
\hline $\begin{array}{l}\text { 7. } \\
\text { Penggunaan Web dengan } \\
\text { php dan dreamweaver }\end{array}$ & 85 & Sangat baik \\
\hline
\end{tabular}

Kemudian dari hasil perhitungan presentase keidealan produk sesuai dengan validasi Teman Sejawat didapatkankan 82,6\% termasuk dalam rentang skor $\bar{X}>81,25$ dalam kategori sangat baik. Untuk peritungan presentase keidealan tiap aspek sesuai dengan tabel 5.

Tabel 5. Presentase dari Teman Sejawat (Peer Review)

\begin{tabular}{|c|c|c|}
\hline Aspek & Persentase dari skor keidealan $(\%)$ & Kategori \\
\hline 1. Aspek isi & 81,25 & Sangat baik \\
\hline 2. Akurasi materi & 93,75 & Sangat baik \\
\hline 3. Merangsang Keingintahuan & 75 & Sangat baik \\
\hline 4. Penyajian & 80 & Sangat baik \\
\hline 5. Tampilan Umum & 85 & Baik \\
\hline 6. Bahasa \& Keterbacaan & 75 & Sangat baik \\
\hline $\begin{array}{l}\text { 7. Penggunaan Web dengan } \\
\text { php dan dreamweaver }\end{array}$ & 85 & Sangat baik \\
\hline
\end{tabular}

Dari data validasi menunjukan dari tiap ahli yang diambil datanya untuk produk bahan ajar rata-rata dalam kategori diatas baik. Tahapan validitas ini sangat diperlukan untuk memperkuat kelayakan dalam pengembangan bahan ajar. Menurut Mohammadnia, \& Moghadam, [14] bahwa buku teks atau bahan ajar yang digunakan sangat penting dalam mengintegrasikan pendidikan untuk pembangunan berkelanjutan. Mesa dkk [15] menyatakan juga bahwa buku maupun bahan ajar yang memiliki fitur dan desain yang berupaya dalam memotivasi dan mengharuskan siswa berinteraksi sangat bagus dalam mendorong siswa dalam belajar. Prasetono dan Trisnawati [16] menyatakan bahwa pentingnya bahan ajar, dalam proses pembelajaran diperlukan bahan ajar untuk arah maupun pedoman dalam belajar selain itu mampu mengembangkan kemampuan berpikir kritis. 
Tahapan ini dilakukan diuji coba kelompok kecil yang dilakukan di mahasiswa teknik informatika yang sudah menempuh mata kuliah pemrograman website. Kelompok kecil diambil random sample dari mahasiswa sebanyak 15 mahasiswa. Dari data kelompok kecil dianalisis didapatkan skor rata-rata 51,13 dalam rentang $\bar{X}>48,8$ dikategorikan sangat baik. Dan untuk presentase keidealan 85,2\% respon siswa diperoleh dan dikategorikan sangat baik. Untuk hasil perhitungan presentase tiap aspek dari angket respon didapatkan sesuai dengan tabel 6.

Tabel 6. Presentase tiap Aspek Respon Kelompok Kecil

\begin{tabular}{|ll|c|c|}
\hline \multicolumn{1}{|c|}{ Aspek } & Persentase dari skor keidealan (\%) & Kategori \\
\hline 1. & Merangsang Keingintahuan & 87,5 & Sangat baik \\
\hline 2. & Penyajian & 87,5 & Sangat baik \\
\hline 3. & Tampilan Umum & 83,3 & Sangat baik \\
\hline 4. & Bahasa \& Keterbacaan & 85 & Sangat baik \\
\hline 5. & Pemanfaatan Bahan Ajar & 85 & Sangat baik \\
\hline
\end{tabular}

Kemudian untuk ujicoba pada kelompok besar dilakukan pada 30 siswa-siswi SMK Karya Bhakti dengan menggunakan pretes dan postes. Didapatkan data penggunaan bahan ajar e-commerce memiliki nilai $\mathrm{N}$-Gain 0,45 yang termasuk dalam rentang $0,7>\mathrm{g} \geq 0,3$ kriteria sedang. Hal ini menunjukan bahwa pengembangan e-commerce untuk meningkatkan kemempuan berwirausaha sebelum dan sesudah penggunakaan, kemudian efektif dan layak untuk dipakai dalam proses pembelajaran.

\section{Kesimpulan}

Dari hasil analisis data dan pembahasan dapat disimpulkan bahwa dari pengembangan bahan ajar e-commerce validasi ahli materi, ahli media dan teman sejawat menunjukan produk dalam kategori sangat baik layak digunakan. Uji coba produk kelompok kecil didapatkan presentase keidealan 85,2\% dan dikategorikan sangat baik. Hasil Nalisis peningkatan kemempuan berwirausaha dari penggunaan bahan ajar e-commerce didapatkan nilai $N$-Gain 0,45 yang termasuk dalam kriteria sedang. Hal ini menunjukan bahwa pengembangan e-commerce untuk meningkatkan kemempuan berwirausaha sebelum dan sesudah penggunaan, kemudian efektif dan layak untuk dipakai dalam proses pembelajaran

\section{Ucapan Terimakasih}

Kami menyampaikan terima kasih yang sebesar-besarnya kepada semua pihak yang mendukung dalam penulisan penelitian yaitu Direktorat Riset dan Pengabdian Kepada Masyakat (DRPM) Ditjen Penguatan Riset dan Pengembangan Kementerian Riset, Teknologi, dan Pendidikan Tinggi, Universitas peradaban dan Fakultas Sains dan Teknologi. Kami juga mengucapkan terimakasih kepada mitra SMK Karya Bhakti atas pelaksanaan kegiatan penelitian ini.

\section{Daftar Pustaka}

[1] Febriantoro, W. (2018). Kajian Dan Strategi Pendukung Perkembangan E-Commerce Bagi UMKM Di Indonesia. Manajerial: Jurnal Manajemen dan Sistem Informasi, 17(2), 184-207.

[2] Mata, F., \& Hernández Ruiz, I. (2019). CRGOURMETCOFFEE. COM: Using ECommerce To Mitigate The Coffee Paradox In Costa Rica. repositorio.una.ac.cr.

[3] Haryono, R. C. S. (2019). Analisis Dan Penilaian Teknologi Informasi Pada Proses Tata Kelola Dengan Cobit 5 Pada Domain EDM Studi Kasus Universitas Peradaban. Indonesian Journal of Business Intelligence (IJUBI), 1(1), 25-31. 
[4] Arifianto, E. Y., \& Coiri, M. (2018). Pemanfaatan E-Commerce Dalam Pebelajaran Manajemen Usaha Kecil Dan Menengah. Jurnal Komunikasi Pendidikan, 2(1), 77-85.

[5] Seprina, I., Suroyo, H., \& Komalasaric, D. (2017). Motivasi Penggunaan E-Commerce dalam Berwirausaha pada Siswa SMK Bina Jaya. Prosiding SISFOTEK, 1(1), 31-36.

[6] Laudon, K. C., \& Traver, C. G. (2016). E-commerce: business, technology, society. PEARSON : England.

[7] Farlina, Y., Hudin, J. M., Yulianti, I., \& Maulana, M. (2019). Rancang Bangun ECommerce Berbantuan Sms Gateway Pada Audrey Batik Sukabumi. Swabumi, 7(1), 14-19.

[8] Li, J., \& Guan, C. (2019). Research on the Practice Model for E-commerce Majors to Start Business in Rural Areas of Hubei Province Against the Background of Rural Revitalization. In The 4th International Conference on Economy, Judicature, Administration and Humanitarian Projects (JAHP 2019). Atlantis Press.

[9] Heshmati, S., Verstichel, J., Esprit, E., \& Berghe, G. V. (2019). Alternative ecommerce delivery policies. EURO Journal on Transportation and Logistics, 8(3), 217248.

[10] Bandara, K., Shi, P., Bergmeir, C., Hewamalage, H., Tran, Q., \& Seaman, B. (2019). Sales Demand Forecast in E-commerce using a Long Short-Term Memory Neural Network Methodology. arXiv preprint arXiv:1901.04028.

[11] Suzuki, S. N., Akimoto, Y., Hirata, K., Ishihara, M., Kameyama, R., Yamaguchi, M., \& Yajima, K. (2019). Development of Android Version Active Textbook System. Procedia Computer Science, 159, 2258-2266.

[12] Daulay, P. (2010). Pemanfaatan Toko Buku Online Untuk Meningkatkan Layanan Distribusi Bahan Ajar Bagi Mahasiswa Universitas Terbuka. Jurnal Pendidikan Terbuka Dan Jarak Jauh, 11(2), 61-74.

[13] Tegeh, I. M., \& Kirna, I. M. (2013). Pengembangan Bahan ajar metode penelitian pendidikan dengan addie model. Jurnal Ika, 11(1).

[14] Mohammadnia, Z., \& Moghadam, F. D. (2019). Textbooks as Resources for Education for Sustainable Development: A Content Analysis. Journal of Teacher Education for Sustainability, 21(1), 103-114.

[15] Mesa, V., Liakos, Y., \& Boelkins, M. (2019). Designing textbooks with enhanced features to increase student interaction and promote instructional change. Calculus in upper secondary and beginning university mathematics, 78.

[16] Prasetyono, R. N., \& Trisnawati, E. (2018). Pengaruh pembelajaran IPA berbasis empat pilar pendidikan terhadap kemampuan berpikir kritis. JIPVA (Jurnal Pendidikan IPA Veteran), 2(2), 162-173. 
Rito Cipta Sigitta H., Rizki Noor Prasetyono 